\title{
Analysis on Financing Difficulties for SMEs due to Asymmetric Information
}

\author{
Cheng Huang, Ya When, Zhifei Liu
}

School of Management, Guangdong University of Technology, Guangzhou, CHINA

\begin{abstract}
Financing is the bottleneck that restricting the development of China's small and medium enterprises. The root cause of financing difficulty for SMEs is the serious information asymmetry that exists between financial institutions, which lead to adverse selection and moral hazard. In this paper, financing theories of SMEs information dissymmetry and credit rationing theories are used to analyze the financing difficulties for SMEs and financing strategies to crack financing difficulty are proposed.
\end{abstract}

Keywords: Small and medium enterprises; information asymmetry; adverse selection; moral hazard; financing strategies

JEL Classification Code: D82, G32

\section{INTRODUCTION}

In China, SMEs have gradually become a great force for promoting economic development. Related data show that SME's financing comes mainly from the external financing of financial intermediaries (eg banks). However, due to the information about SME's business status and credit status is not totally known to banks, they tend to consciously cut down loans lending to SMEs. This is exactly what we call "credit rationing" behavior. As a result, many small and medium enterprises will be forced to close down for lack of funds. Therefore, how to break financing barriers facing SME under asymmetric information, and promote the growth and development of SMEs to make full use of its role played in economic development, can be said are currently the most pressing problems to be solved.

\section{ANALYSIS ON IMPACT OF INFORMATION ASYMMETRY ON FINANCING BEHAVIOR}

The root cause of the small and medium-sized enterprise financing difficulties lies in the serious information asymmetry that exists between SMEs and financial institutions. Asymmetric information means that one party has access to relevant information, while the other is lack of the relevant information, or the information is no more than the former has. Unfortunately, lack of relevant information would have adverse impacts on decision-making of the latter party, further lead to inefficiency of resource allocation. In fact, Asymmetric information can be divided into ex ante informational asymmetries and information asymmetry. Ex ante asymmetric information can lead to adverse selection, information asymmetry leads to moral hazard. Applying the theory of asymmetric information to analyze 
credit market scan provide a theoretical basis to resolve financing problem bothering the small and medium-sized enterprise.

\section{Information asymmetry leads to adverse selection}

"Adverse selection" happens when information related to the borrower's credit, project risk and benefits are known more by borrowers than financial institutions. In other words, the borrowers have a relative information advantage. Therefore, financial institutions, in the relative disadvantaged position, are only able to raise lending rates to reduce potential risk of credit losses. However, rising interest rate of loans may lead to those normal, blue-chip companies withdraw from the lending market because they do not want to pay the premiums in terms of market interest rates. On the other hand, those companies who having poor business performance or pure cheater tend to acquire loans from banks as they willing to pay higher interest rate. Strange as it seems to be, loan interest rate may turn out to reduce, rather than increase, bank earnings. In this case, most of banks would probably choose relatively low interest rates and refuse part of the demand for loans, rather than select higher interest rates and try to meet all of the borrowers' demand for loans. This is so-called the first kind of "credit rationing" behavior ( $\mathrm{Li}$ and Cheng, 2005). To be more precise, among all the applications for loan, some got being admitted while some others are denied, even when the SMEs willing to paid more interest. Because of the relative weakness of small and medium enterprises themselves, compared with larger enterprises, it is understandable that SMEs become the main targets been administered "credit rationing". Many SMEs have been eliminated from market because of lacking the access to loans. Thus, asymmetric information leads to adverse selection which would aggravate the financing difficulty for SMEs.

\section{Information asymmetry leads to moral hazard}

Moral hazard in financial markets occurs when the borrower has already acquired the loan. Due to the financial institutions are unable to supervise the borrowing company all the time and obtain effective information about the borrower's willingness to pay back loans, business performance, and where the loan go, there are chances that borrowing company may violate the original commitment they made when signing the loan contract, and engage in high-risk investment or intentionally flight from debt. In other words, as banks cannot completely know and control what indeed the borrowers use loans for and whether they would pay the money back or not, the borrowers are likely to take risks to default on the engagement. This opportunistic practice, what we know as moral hazard, could lead to bad debt which could take its toll on banks. To guarantee loan safety and profitability, banks and other financial institutions, for one thing, will implement "credit rationing" policy. That is reducing lending to SMEs to avoid moral hazard, which is what we called the second Act of "credit rationing" (Wang, 2012). Precisely speaking, the applicant's borrowing requirement will only partially be met (such as applying for 100 million, but only receiving 20 million), which can lead to atrophy of the SME loan market. For the other, financial institutions may raise loan threshold, strengthen SMEs credit appraisal and management, in order to reduce the lending losses arise from the moral hazard. However, this reaction will boost the transaction costs between banks and enterprises dramatically. In addition, SMEs also have difficulty to come up with satisfying mortgages to the financial institution. Therefore, financial institutions may not dare to lend any loans to SMEs. To conclude, asymmetric information leads to moral hazard, which would further exacerbate the financing difficulties of SMEs. 


\section{The transaction cost increase caused by asymmetric information}

Transaction cost can be divided into two kinds. One happens before signing the contract with any borrowers, which we can call "searching cost". Due to the asymmetric information, the bank has to take efforts in terms of money and time to search for information which can reflect the real situation of the enterprise to ensure the safety and efficiency of loans and prevent the borrower fraud. These information varying from financial statements, the credit rating level to quality of management, cash flow, business prospects, and so forth. However, information related to this is not easy to obtain the credit market, because most of which are highly internalized and not accessible, which will drive up the cost on information searching. In fact, the more incomplete and the less transparent the information is, the higher searching cost will be.

The other transaction cost is loan-after supervision cost. To prevent borrowing enterprise from gambling behavior and speculation, the banks also need certain cost on supervising. But most small and medium-sized enterprises are family-owned and implement extensive management, their financial accounting practices, and most often, are not standard. So the financial information obtained by banks is often inaccurate and can't reflect the real situation of SMEs, making the process of information searching and supervising even more difficult. In addition, loans to small and medium-sized enterprise are small in scale but much higher in frequencies, which could enhance the supervision cost per unit (Zhong, 2008).

By contrast, large enterprises have very huge advantage in aspects such as the credit rating, valuable mortgage. Meanwhile, information of them is relatively transparent and accessible. All of these advantages can effectively reduce the cost on searching for information of transaction object and cost of supervision. Comparing the cost, benefit and risk among different types of enterprises, financial institutions will inevitably resort to large enterprises by reducing the loan to small and medium-sized enterprises, which further aggravate the financing difficulty facing the small and medium-sized enterprise.

\section{COUNTER MeAsure of FinANCING DifFiculty UNDER Asymmetric Information}

\section{The SMEs themselves need to strengthen their internal governance mechanism}

At present, it is common that Chinese SMEs have several universal problems, such as having unsound corporate financial system and inaccuracy financial reports. SMEs should strengthen their internal governance mechanism, and improve the standardization of the enterprise's financial system and enterprise information transparency. Moreover, SMEs should offer effective financial reports with high authenticity to help commercial banks make judgments. Besides, SMEs should pay more attention to the credit consciousness and set up a good credit image to financial institutions. When the credit level of enterprise has risen, financial institutions will change their impression toward SMEs, and banks will change their credit orientation. Hence, the financing difficulties will be handled completely.

\section{Developing and standardizing local small and medium financial institutions}

Regional and local small and medium financial institutions have a relative advantage in terms of low transaction costs and information when providing financing support for SMEs. That is because local mall and medium financial institutions are more accessible to local information and can make full use of them. Thus, they can easily gather information about operational performance, development prospects and credit rating level of SMEs, at a relative lower cost .what's more important, they also have comparative advantages in credit 
screening and loan-after supervision of SMEs, by which they easily overcome information asymmetry that can lead to the problems of moral hazard and high transaction costs.

\section{Developing the multi-level financial market}

Firstly, continuing to push forward construction of Growth Enterprise Board Market. Government should simplify procedures, reduce the financing cost, actively provides more financing opportunities for those small and medium-sized enterprises which have high growth, small scale, and weak ability for resisting risk. Allowing some normative private companies with good profits to trade at the counter and establishing over-thecounter market (Zhong, 2003). In addition, actively broaden the bond financing channels, cancel credit limit that is adverse to small and medium-sized enterprise. Allow the outstanding small and medium-sized enterprise financing through the issuance of enterprise bonds.

Above all, diversifying the indirect financing channel .To achieve this, government need to update the ideas and take effective measures to motivate bank lending loan to SMEs. For example, implement the indiscriminate financing policy regardless of it is a large-scale and mature enterprise or it is just a small and starting one. Simplify the process of verificationcancelation of non-performing loans to small and medium enterprises.

\section{CONCLUSION}

Information asymmetry leads to adverse selection and moral hazard. Not only it will make a large number of SMEs which have good potential of growth have no access to loans but also cause banks and other financing institutions reluctant to lend to SMEs. To solve this, SMEs themselves, as loan-need side, should improve the level of management, reducing moral hazard. As a loan-supply side, financial institutions should investigate information about corporate financial status, to hold back financing market's adverse selection. At this stage the government should, first of all, promote the construction of small and mediumsized enterprise board market, which means to broaden the direct financing channels of small and medium-sized enterprises. Then, actively developing and standardizing local small and medium financial institutions to fulfill its advantage in indirect financing.

\section{REFERENCES}

Li,W. and Cheng, J.H. (2005). Financing feasibility analysis of small and medium-sized enterprise based on asymmetric information. World Economy, no.11, PP.71-77.

Wang, F.R. (2012). Analysis on SMEs' financing difficulties under asymmetric information, China Securities and Futures, no.10, PP.267-268,.

Zhong, B.(2008). Economic analysis on the financing difficulty of small and medium enterprises: based on the perspective of information asymmetry. Economist, no.01, PP.225-226.

Zhong, T.L. and Ming, Y.X. (2003). Information asymmetry and market failure in small and medium enterprises financing. Accounting Research, no. 8, PP.42-44. 